\title{
Radiation effect of fractal sierpinski square patch antenna
}

\author{
Khalid Hussein Kuther, Israa Hazem Ali, Riyadh Khlf Ahmed \\ Department of Communication Engineering, Collage of Engineering, University of Diyala, Iraq
}

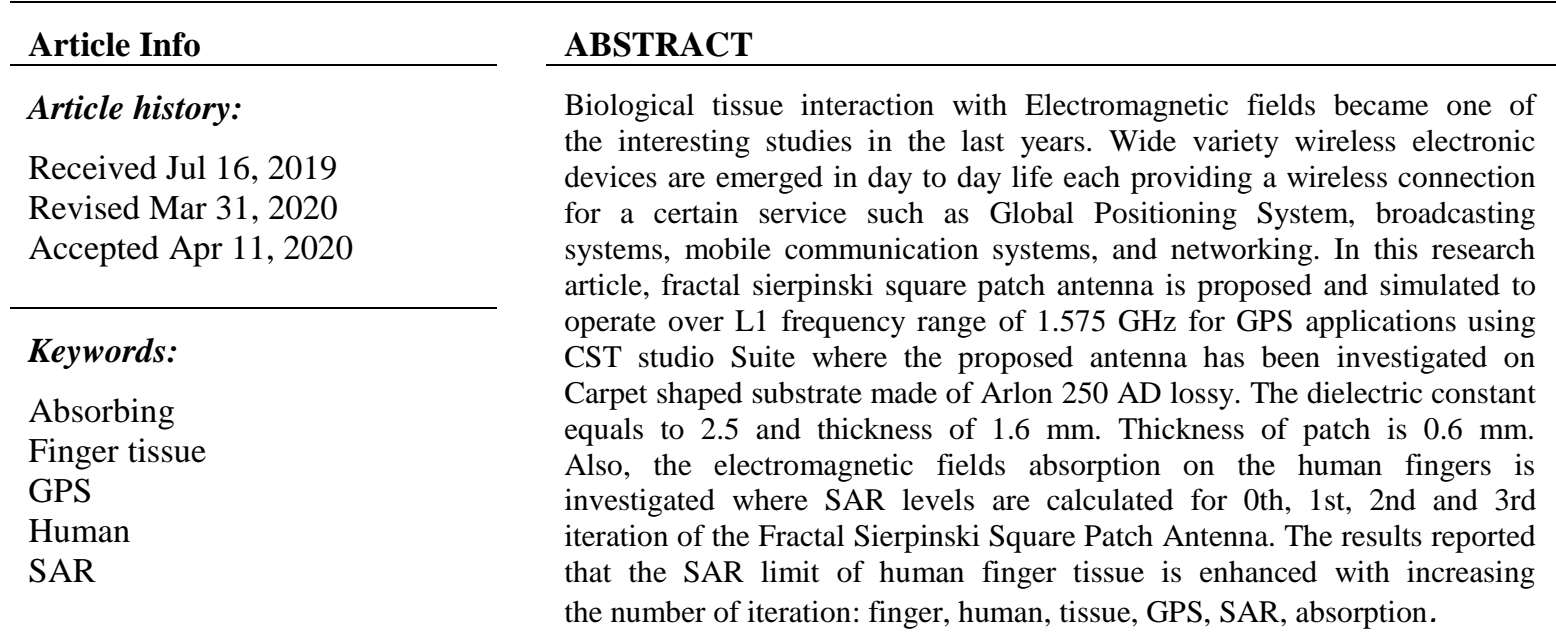

Copyright $\odot 2020$ Institute of Advanced Engineering and Science. All rights reserved.

\section{Corresponding Author:}

Israa Hazem Ali,

Department of Communication Engineering,

Collage of Engineering, University of Diyala,

Baquba, Diyala 32002, Iraq.

Email:pg_student75@yahoo.com

\section{INTRODUCTION}

In the last three decades, small size, high efficiency and high performance antennas have been in wide demand in order to meet the integration for multiple telecommunication services. Square patch micro strip antenna is one of these kinds which has attracted by communication engineers. Microstrip antenna is constructed from three layers: Radiated patch component, dielectric substrate, and ground plane [1-5].

SAR limit is the ratio of the amount of power measured in watt to the average mass measured in gram. SAR is affected antenna kinds, the distance between antenna location and the human body, radiation patterns and radiated power [6,7]. There are different approaches to SAR reduction, first approach is implemented by changing the angle of Electromagnetic source in relation to human body such as skin, brain and bone, second approach is investigated using fractal theory to reduce the size of antenna or changing the type of material covering the radiator [8]. SAR is determined mathematically by dividing the product of conductivity with square of the root mean square value of the electric field strength $(\mathrm{E})$ to the volume density in certain tissue [9]:

$$
\mathrm{SAR}=\sigma^{*} \mathrm{E} 2 / 2 \rho
$$

Where $\mathrm{E}$ denotes electric field strength in unit of $\mathrm{v} / \mathrm{m}, \sigma$ is conductivity measured in $(\mathrm{S} / \mathrm{m})$ and $\rho$ is the density $(\mathrm{Kg} / \mathrm{m} 3)$ of the interest tissue. Two standards introduce the SAR limit. First standard is IEEE C95.1: 1999 and the other standard is IEEE C95.1: 2005 which is comparable to the absorption limit expressed in ICNIRP. SAR limit of IEEE C95.1: 1999 can be expressed as1.6W/Kg in a SAR $1 \mathrm{gm}$ averaging mass while SAR limit in the second kind is updated to $2 \mathrm{~W} / \mathrm{Kg}$ in a $10 \mathrm{gm}$ averaging mass [10-12]. 
SAR limit was determined for Fractal Sausage Minkowski patch antenna for human head antenna [13]. The increasing the dielectric constant for substrate material will be increased the SAR limit for both IEEE and FCC standards [14]. Reducing the interface between human body and the radiator element was achieved using ferrite materials and Meta materials [15]. Four different human hand tissues are involved: skin, bone, muscle, and tendon in addition to three homogeneous sets of hands Using (SAM) hand phantom dielectric characteristics was presented [16]. The power is increased or decreased significantly in the experiment phase in some wavelengths when compared to the certain phases [17]. Study the mechanism of Electromagnetic waves absorption in both human hands and fingers was reported [18]. Study the impact of electromagnetic wave absorption on hand with respect to radiator element prosperities [19].

Enhancement of Body Flex application for allowing a suitable motion of the forearm and the wrist where the application is necessary for study the performance of electromagnetic effects from wireless phones [20]. Test of thirteen phones reported that various size dielectric slabs may increase the SAR measurements but cannot be representative of the high variations caused by a real hand [21]. SAR limit reduction was studied for four different iterations of Sausage Minkowski radiator element [22, 23]. In this research article, Fractal Sierpinski Square patch antenna for GPS applications was proposed and simulated. On other hand comprehensive study of radiation effect for this type of antenna on human finger is represented

\section{METHODOLOGY AND MATERIALS}

The suggested fractal antenna based on Carpet Sierpinski is simulated from square patch dimensions of Length (Lc) x Width (Wc) x Thickness (hc) equal to $115 \mathrm{~mm}$ x $115 \mathrm{~mm} \times 1.6 \mathrm{~mm}$ for substrate and ground layers. Substrate is selected according to dielectric constant (cr) of 2.5. Patch layer dimension is adjusted to operate in resonance frequency according to number of iteration. The simulation results are presented in triple iterations are designed using CST studio suite software 2014. First step is the determination of a square shape dimension [24-28]. The next step consists of division of it to nine tiny congruent squares. The open central square is dropped. The remaining eight squares are surrounded with eight smaller identical squares. Fractal dimension Dsi of a set $\mathrm{A}$ is expressed according to (2):

$$
\mathrm{Dsi}=\log (\mathrm{Ni}) / \log (\mathrm{ri})
$$

where Ni denotes the number of distinct copies identical to A, and A is reduced down by a ratio of 1/ri. Figure 1 shows the configuration details of Carpet Sierpinski fractal Square patch antenna for 0th iteration, 1st iteration, 2nd iteration and 3rd iteration respectively [29]. The third step involved the measurements of antenna radiation effect on human fingers tissue model based in two world standard ICNIRP and IEEE.

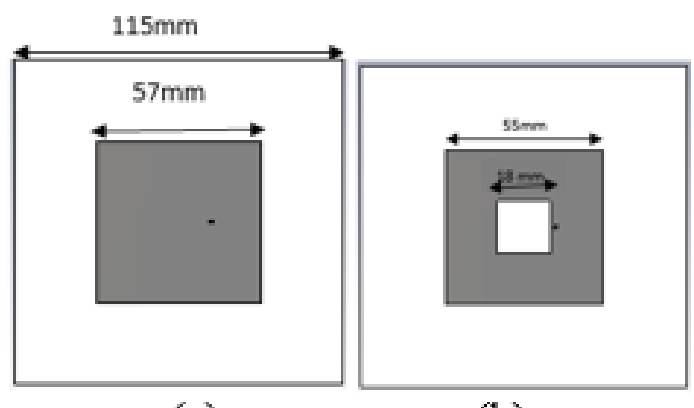

(a)

(b)

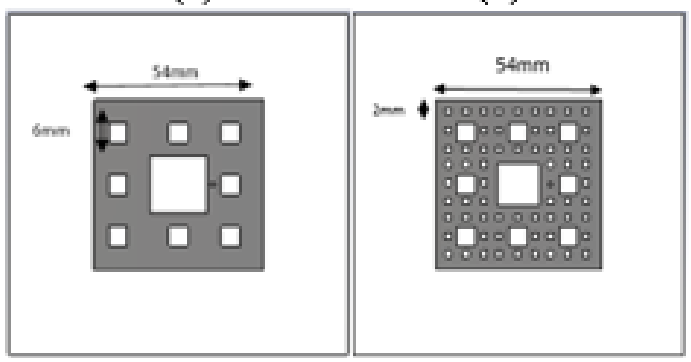

(c)

(d)

Figure 1. The geometry details of fractal carpet sierpinski SPA 


\section{RESULTS AND DISCUSSION}

Firstly, Fractal Carpet Sierpinski based on Square patch antenna is designed and simulated. The simulation and results are carried out using CST software 2014. Four various iterations is designed to use in applications of GPS. The geometrical configuration of patch radiator is crossbred and utilizing dielectric material (Arlon $250 \mathrm{AD}$ lossy) as substrate. The substrate is described with relative permittivity $\varepsilon_{r}=2.5$, and thickness $(\mathrm{h} c=1.6 \mathrm{~mm})$. The ground material is made of copper with thickness of $0.1 \mathrm{~mm}$. The simulation results of reflection coefficient, gain, VSWR and the reduced area of the patch are shown in Table 1. From the observations from the Table 1, good indicator is recorded for the results. Reflection coefficient is decreased from (- 17 to -25$) \mathrm{dB}$ with respect to the increasing of the number of iteration. The other parameters which are gain, directivity and voltage standing wave ratio are simulated. Maximum directivity values were recorded 7.52, 7.51, 7.50, 7.48 for number of iteration from 0th to 3rd respectively. Also, the gain of all modes of iteration has good agreement which was $5.48 \mathrm{~dB}, 5.74 \mathrm{~dB}, 6.15 \mathrm{~dB}$ and $7.29 \mathrm{~dB}$ for the iteration number from 0 th to 3 rd respectively as shown in Table 1.

Table 1. The characteristics of fractal carpet sierpinski square patch antenna

\begin{tabular}{lcccc}
\hline Characteristics & \multicolumn{4}{c}{ Types of Fractal } \\
& $0^{\text {th }}$ iteration & $1^{\text {st }}$ iteration & $2^{\text {nd }}$ iteration & $3^{\text {rd }}$ iteration \\
\hline Reflection coefficient $(\mathrm{dB})$ & -16 & -18 & -25 & -27 \\
Bandwidth $(\mathrm{MHz})$ & 44 & 31.4 & 29 & 28 \\
Gain $(\mathrm{dB})$ & 5.48 & 5.74 & 6.15 & 7.29 \\
Directivity $(\mathrm{dBi})$ & 7.52 & 7.51 & 7.50 & 7.48 \\
VSWR & 1.65 & 1.65 & 1.7 & 1.6 \\
Area of patch $\left(\mathrm{mm}^{2}\right)$ & 3249 & 2701 & 2304 & 2052 \\
\hline
\end{tabular}

The next step of our study is calculation of SAR limit for human fingers tissue model. Basically, the structure of human fingers tissue model contains three layers' bone, meat and skin. The proposed antenna is positioned at fixed distance about $5 \mathrm{~mm}$ from the human fingers. Figures 2-5 show that the SAR simulation results for the proposed antennas.
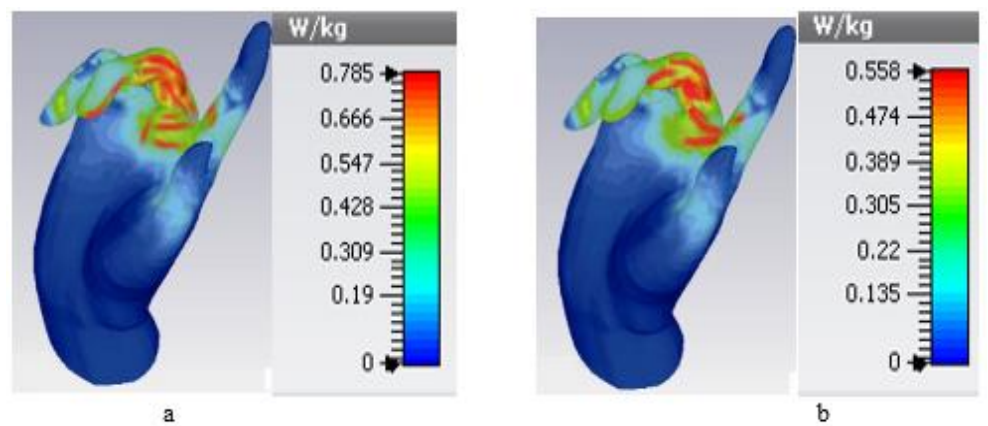

Figure 2. Specific absorbing rate (SAR) for SPA with 0 iteration, (a) $1 \mathrm{~g}$, (b) $10 \mathrm{~g}$
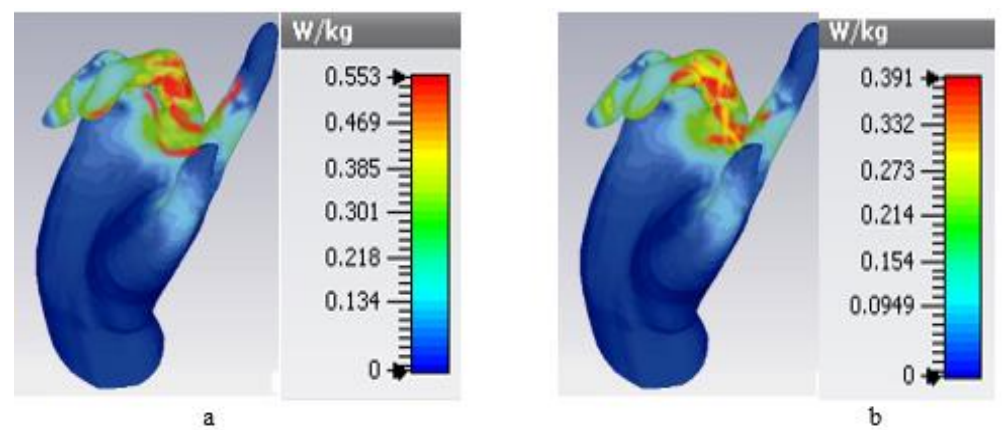

Figure 3. Specific absorbing rate (SAR) for SPA with $1^{\text {st }}$ iteration, (a) $1 \mathrm{~g}$, (b) $10 \mathrm{~g}$ 

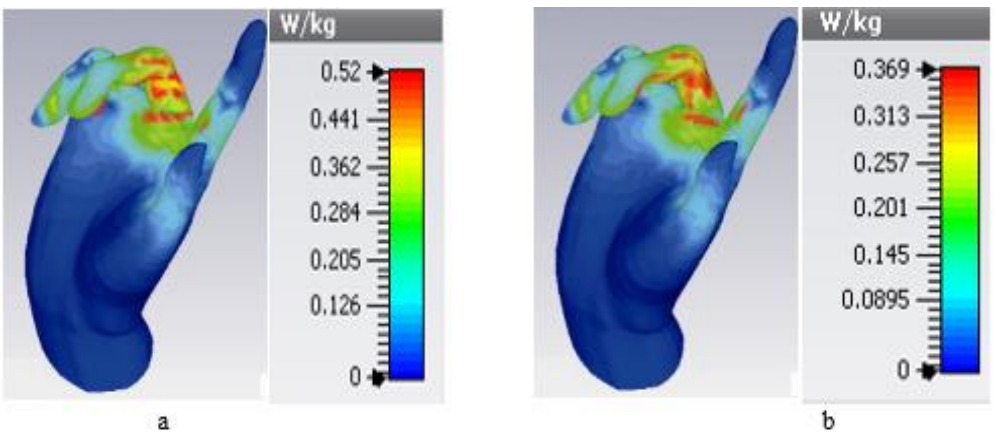

Figure 4. Specific absorbing rate (SAR) for SPA with $2^{\text {nd }}$ iteration, (a) $1 \mathrm{~g}$, (b) $10 \mathrm{~g}$
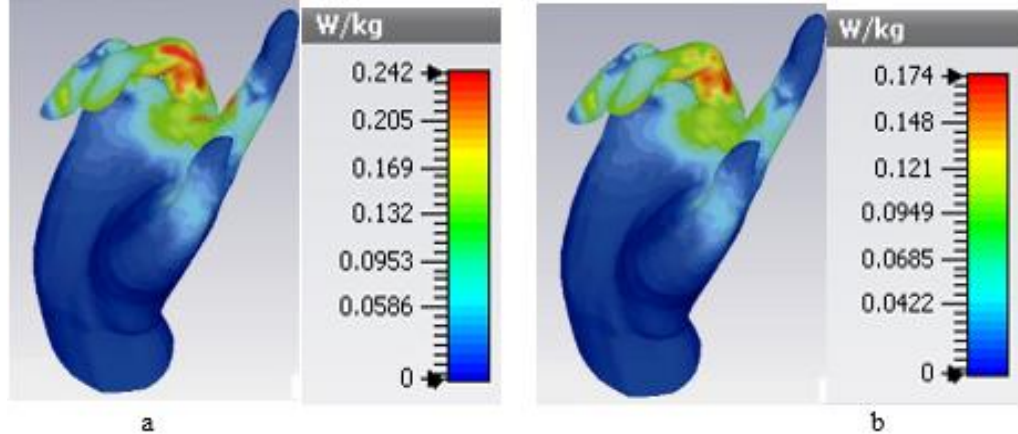

Figure 5. Specific absorbing rate (SAR) for SPA with $3^{\text {rd }}$ iteration, (a) $1 \mathrm{~g}$, (b) $10 \mathrm{~g}$

As shown in Table 2 where the SAR value is improved gradually with increasing the number of iteration. The red color indicates the region of fingers tissue which absorbed the maximum energy of radiated E.M fields from the proposed antenna. From Table 2, the low SAR value at all the resonance frequencies is noticed to satisfy the international safety standards (FCC \& ICNIPR) at ( $1 \mathrm{~g} \& 10 \mathrm{~g}$ ). The proposed 3rd iteration of the fractal antenna has a very low SAR value.

Table 2. Values of peak SAR for fractal carpet sierpinski antenna

\begin{tabular}{ccc}
\hline Iteration of Fractal & \multicolumn{2}{c}{ SAR $(\mathrm{W} / \mathrm{Kg})$} \\
& $1 \mathrm{~g}$ & $10 \mathrm{~g}$ \\
\hline $0^{\text {th }}$ & 0.785 & 0.558 \\
$1^{\text {st }}$ & 0.553 & 0.391 \\
$2^{\text {nd }}$ & 0.52 & 0.369 \\
$3^{\text {rd }}$ & 0.242 & 0.174 \\
\hline
\end{tabular}

\section{CONCLUSION AND FUTURE WORK}

A novel and compact Fractal carpet sierpinski patch antenna has been designed and investigated. The proposed tiny antenna operates in L- band of $1.575 \mathrm{GHz}$ for navigation system. High demand for new kinds of antenna for modern communication applications motivates the researchers to study the radiation effect on human health. SAR is considered as a crucial factor and must be taken on account for many industrial applications. Therefore, new design is introduced and fabricated to enhance the SAR limit. A design and simulation show that the characteristics of the antenna will be enhanced in parallel with the increasing the number of fractal iteration like gain, directivity, radiation pattern, SWVR and return loss. In addition, the values of SAR for 1st, 2nd and 3rd iteration indicate that SAR levels will be decreased with increasing the number of iteration. The results are compatible with the yearly reports limits of the two standards (ICNIRP\&IEEE). As a conclusion, the investigation of high efficiency, low size and not expensive antenna using simple technique, SAR is reduced as parallel with fractal process and the proposed antenna can be used for navigation purpose. Finally, we concluded that reducible values for low SAR level of radiator device (antenna) for human fingers will never degrade the RF performance of antenna. The suggestion is study the radiation effect of this type of antenna on human head or other part of human body. 


\section{REFERENCES}

[1] A. Sabah, and M. J. Frhan, "A new patch antenna for ultra-wide band communication applications," Indonesian Journal of Electrical Engineering and Computer Science (IJEECS), vol. 18, no. 2, pp. 848-855, 2019

[2] Adel Y. I. Ashyap, et al., "A wearable antenna based on fabric materials with circular polarization for body-centric wireless communications," Indonesian Journal of Electrical Engineering and Computer Science (IJEECS), vol. 15, no. 3, pp. 1509-1516, 2019.

[3] A. D. Farhood, et al., "Design and analysis of dual band integrated hexagonal shaped microstrip UWB antenna," Indonesian Journal of Electrical Engineering and Computer Science (IJEECS), vol. 15, no. 2, pp. 861-869, 2019.

[4] R. H. Thaher, and N. B. Hassan, "Design of p-shaped microstrip patch antenna for wireless communication systems," Proc. EECSI, 2017.

[5] M. ElJourmi, H. Ouahmane, and F. Kharroubi, "Design and simulation of UWB microstrip patch antenna for Ku/K bands applications," International Journal of Electrical and Computer Engineering (IJECE), vol. 9, no. 6, pp. 4845-4849, 2019.

[6] T. Khalifa, N. M. Sahar, N. Ramli, M. T. Islam "Circularly polarized microstrip patch antenna array for GPS application," Indonesian Journal of Electrical Engineering and Computer Science (IJEECS), vol. 15, no. 2, pp. 920-926, 2019.

[7] S. Alani, Z. Zakaria, A. Ahmad, "UWB elliptical patch antenna for skin cancer diagnosis imaging," International Journal of Electrical and Computer Engineering (IJECE), vol. 10, no. 2, pp. 1422-1429, 2020.

[8] A. Othman, N. I. S. Shaari, A. M. Zobilah, N. A. Shairi, and Z. Zakaria, "Design of compact ultra-wideband antenna for microwave medical imaging application," Indonesian Journal of Electrical Engineering and Computer Science (IJEECS), vol. 15, no. 3, pp. 1197-1202, 2019.

[9] Z. Ghazali, M. H. Mat, H. A. Rahim, and A. Syafiq, "A Review on Level of Specific Absorption Rate Due to High Power Transmission Lines: Analysis toward Human Position Posture," MATEC Web of Conferences, 2016.

[10] IEEE C95.1-2005, "IEEE standards for safety levels with respect to human exposure to radio frequency electromagnetic fields, $3 \mathrm{kHz}$ to $300 \mathrm{GHz}$," Institute of Electrical and Electronics Engineers, New York, NY, 2005.

[11] International Non-Ionizing Radiation Committee of the International Radiation Protection Association, "Guidelines on limits on exposure to radio frequency electromagnetic fields in the frequency range from $100 \mathrm{kHz}$ to $300 \mathrm{GHz}$," Health Physics, vol. 54, no. 1, pp. 115-123, 1988.

[12] Alani, Zahriladha Zakaria and A. Ahmad, "UWB elliptical patch antenna for skin cancer diagnosis imaging Sameer," International Journal of Electrical and Computer Engineering, vol. 10, no. 2, pp. 1422-1429, 2020.

[13] Israa H. Ali and Riyadh Khlf Ahmed "The Performance Evaluation of SAR for a Sausage Minkowski Square Patch Antenna” Al-Nahrain Journal for Engineering Sciences, vol. 21, no. 2, pp. 208-212, 2018.

[14] Muhammad Afiq Abdul Aziz, Norhudah Seman and Tien Han Chua, "Microstrip antenna design with partial ground at frequencies above $20 \mathrm{GHz}$ for $5 \mathrm{G}$ telecommunication systems," Indonesian Journal of Electrical Engineering and Computer Science (IJEECS), vol. 15, no. 3, pp. 1466-1473, 2019.

[15] Israa H. Ali and R. Khlf Ahmed, "The Effects Evaluation of Various Dielectric Substrate of Square Patch Antenna on SAR Level for Human Head," Journal of engineering and applied sciences, vol. 13, no. 9, pp. 2761-2766, 2018.

[16] M.T.Islam, M. R. I. Faruque, N. Misran, "Reduction of Specific Absorption Rate (SAR) in the human head with ferrite material and meta material," Progress In Electromagnetics Research, vol. 9, pp. 47-58, 2009.

[17] S. H. Ronald, M. F. A. Malek, S. I. S. Hassan, C. E. Meng, M. H. Mat, M. S. Zulkei, and S. F. Maharimi "Designing Asian-Sized Hand Model For Sar Determination At Gsm900/1800: Simulation Part," Progress in Electromagnetics Research, vol. 129, pp. 439-467, 2012.

[18] Randall L. Waechter, M. A. and L. Sergio "Manipulation Of The Electromagnetic Spectrum Via Fields Projected From Human Hands: A Qi Energy Connection?," Subtle Energies and Energy Medicine, vol. 13, no. 3, pp. 233-250, 2002.

[19] Chung-Huan Li, Mark Douglas, ErdemOfli, Nicolas Chavannes, Member, Q. Balzano, and Niels Kuster "Mechanisms of RF Electromagnetic Field Absorption in Human Hands and Fingers," IEEE Transactions On Microwave Theory And Techniques, vol. 60, no. 7, pp. 2267-2276, 2012.

[20] M. R. I. Faruque, M. I. Hossain "Effects Of Hand On Em Absorption And Antenna Performances For Internal Handset Pifa," Development Of Anew Metamaterial Antenna For Filter Application, pp. 459-467, 2017.

[21] M. Vuchkovikj, I. Munteanu, and T. Weiland, "Application of postured human model for SAR measurements," Advances in Radio Science, vol. 11, pp. 347-352, 2013.

[22] Chinthana J Panagamuwa, Ian Howells and Amir Kotb, "Use of a block hand phantom for mobile phone specific absorption rate measurements," 7th European Conference on Antennas and Propagation, pp. 911-914, 2013.

[23] Riyadh Khlf Ahmed, Israa H. Ali, "SAR level Reduction Based on Fractal Sausage Minkowski Square Patch Antenna," Journal of communications, vol. 14, no. 1, pp. 82-87, 2019.

[24] Shahid M Ali, Varun Jeoti, Tale Saeidi, Wong Peng Wen, "Design of compact microstrip patch antenna for WBAN applications at ISM $2.4 \mathrm{GHz}, "$ Indonesian Journal of Electrical Engineering and Computer Science (IJEECS), vol. 15 , no. 3, pp. 1509-1516, 2019.

[25] Akram El Hamdouni, et al., "Novel fractal antenna for UWB applications usingthe coplanar waveguide feed line," International Journal of Electrical and Computer Engineering (IJECE), vol. 9, no. 4, pp. 3115-3120, 2019.

[26] Y. Rahayu and R. A. Gusma, "Simulation of 6 Elements Aperture Coupled Feed Planar Array Rectangular Microstrip Patch Antenna for CPE WiMAX Application at $3.3 \mathrm{GHz}$," Proceeding of International Conference on Electrical Engineering, Computer Science and Informatics (EECSI 2014), pp. 451-455, 2014.

[27] A. Zaidi, A. Baghdad, A.Ballouk, and A. Badri, "Design and Optimization of a High Gain Multiband Patch Antenna for Millimeter Wave Applications" International Journal of Electrical and Computer Engineering (IJECE), vol. 8, no. 5, pp. 2942-2950, 2018. 
[28] Mohammed ElJourmi, H. Ouahmane, and F. Kharroubi, "Design and simulation of UWB microstrip patch antenna for $\mathrm{Ku} / \mathrm{K}$ bands applications," International Journal of Electrical and Computer Engineering (IJECE), vol. 9, no. 6, pp. 4845-4849, 2019.

[29] Israa H. Ali, and R. K. Ahmed, "Fractal Sierpinski Square Patch Antenna for GPS Applications," IOP Conference Series: Materials Science and Engineering, vol. 518, no. 4, pp. 1-6, 2019.

\section{BIOGRAPHIES OF AUTHORS}

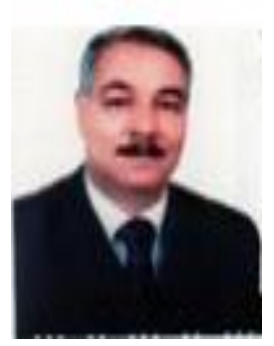

Khalid Hussein Kuther received the degree in Electrical Engineering from college of Engineering/ University of Baghdad. Master degree was received in 2000 from Baghdad University. Currently, he is a Lecturer at Communication Engineering/ collage of Engineering/ University of Diyala.

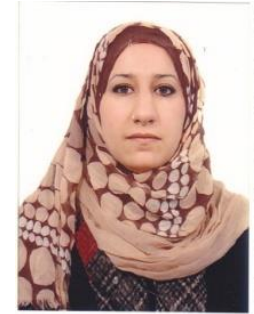

Israa H. Ali received the degree in Electronic Engineering from college of Engineering/ University of Diyala, in 2005.Master degree was received in 2013 from Almustansiriya University. Currently, she is a Lecturer at Communication Engineering/ collage of Engineering/ University of Diyala.

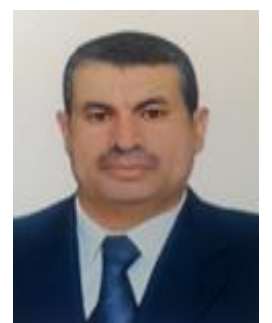

Riyadh Khlf Ahmed received the degree in Electronic and communication Engineering from college of Engineering/ University of Mosul, in 1993. Master degree was received in 2005 from University of Technology. Ph.D was received in 2014 from university of Baghdad. Currently, he is Lecturer at Communication Engineering/ college of Engineering/ University of Diyala. 